\title{
Individual Perceptions Of Innovation: A Multi-Dimensional Construct
}

Ervin. L. Caraballo, DIBA, Capella University, Minneapolis, USA

Gregory C. McLaughlin, DBA Capella University, Minneapolis, USA

\begin{abstract}
The purpose of the research was to understand and quantify how individuals perceive the meaning of the word innovation across a specific, indentified relatively homogenous cultural group. A traditional definition of innovation generally refers to the creation of a new or novel product or service. The intent was to demonstrate that a uniquely identified cultural group, involving a homogeneous group of IT industry employees accustomed to frequent innovations, might perceive a different meaning of innovation. This paper presents findings that redefine innovation, as a three-dimensional construct. Factor analysis identifies the constructs as new, improve or change. Individuals understand the meaning of innovation in these three unique (and independent) dimensions. In addition, three independent demographic variables (gender, job function, and generational cohort) suggest that variations in the perception of innovation are job-related and age dependent. Implications are that innovation is a complex concept, adapted by individuals, to describe something more than a new product or service.
\end{abstract}

Keywords: Innovation Perception; Innovation; Multi-Dimensional Construct

\section{INTRODUCTION}

$\mathscr{I}$<smiles>[CH]</smiles>
nnovation is a critical need for all organizations as it adds value and sustains competitive advantage (Baregheh, Rowley, and Sambrook, 2009, p.1323). Businesses need to innovate to increase performance (McLaughlin, McLaughlin and Preziosi (2004) and as a primary source of wealth creation (de Waal, Maritz, and Shieh, 201). Innovation is a concept that extends to products, processes, and services. There is a necessity for involving personnel in innovation projects for both competitive advantage and human perspective, as ideas and needs drives innovation.

Given its critical function, innovation should be a readily identified concept that has a generally accepted definition. Flight, Allaway, Kim and D'Souza (2011) state that ability to measure how individuals perceive innovation is important for identifying problems related to success. Baregheh, et al. (2009), identified over 60 unique definitions of innovation collected from disciplines such as management, economics, technology, knowledge management and marketing. Given that innovation is a key ingredient for success, is there a simple but effective method of understanding innovation from an individual perspective? In addition, many definitions of innovation exist at the managerial, technical, and functional level. Finally, is there a difference between individual perceptions of innovation across demographic categorizations of gender, job function, and age (generational cohort)?

The authors will attempt to answer these questions. The first section will explore a possible definition of innovation generated from an individual's perception. The second section presents how the research has advanced on this topic. Finally, an exploratory and descriptive analysis compares and contrasts individual perceptions of innovation, from a relatively homogeneous sample of Latino Americans employed within multiple companies of the IT industry. 


\section{UNDERSTANDING THE DEFINITION OF INNOVATION}

Although there are many specific definitions of innovation, a central theme prevails that describes innovation as something new or unique (product or service) (Baregheh, et al., 2009). An invention is the common result of the innovation process. From a historical perspective, Thompson $(1965$, p. 2$)$ defines innovation as, "the generation, acceptance, and implementation of new ideas, processes products and services." A more recent definition by Wang, et al., states that innovation is "conceptually a process that begins with a novel idea and concludes with market introduction" (2010, p. 767). Therefore, innovation begins with a new idea and ends with a marketable product or service. Yet, in reality, innovation is more than new ideas; it is new technology, new ways of operating, and new paradigms of management. According to Baregheh, et. al. (2009), definitions of innovation today contains elements that overlap and often seem contradictory. This leads to "a situation in which there is no clear and authoritative definition of innovation" (Baregheh, et al., 2009, p. 1324). Yet, innovation occurs when humans employ a creative process to meet a particular need: innovation begins at a very human level.

Definitions for innovation range from those related to organizational innovation to technical and individual perceptions of innovation. It is understandable that the definitions of innovation are content specific. In order to clarify a definition of innovation that will relate to an individual's perception, the authors decided to examine the "means of innovation" (Baregheh et al., 2009, p. 1334); that is, understanding how innovation "transforms ideas into new, improved or changed entities" (Baregheh, et al., 2009, p. 1334). This understanding brings innovation to an individual perspective. Spence (1994) defines innovation as something that has never previously existed. Conversely, it could be something quite new to our own personal situation or capable of having a fresh use at the time we become aware of it (p.25). This definition incorporates an understanding of innovation viewed from a human perspective.

A more precise way of understanding innovation comes from the work of Zhuang (1995) and Zhuang, Williamson, and Carter (1999), whose definition clarifies innovation to mean one or all of the following:

1. An invention, i.e, creation of something entirely new;

2. An improvement, i.e., a refinement of what has been developed;

3. The diffusion or adoption of innovation developed elsewhere (Zhuang, et al., 1999) p. 58).

Innovation is a multi-faceted process, not a single or discrete act (Baregheh, et al., 2009, p. 1334) involving people, process and technology. Therefore, an understanding of innovation should be specific to the intent of the desired outcome. In fact, its multi-faceted, multi-dimensional set of characteristics precludes a "one size fits all" approach. Innovation is, in fact, outcome dependent (Zhuang, 1995) and the definition should reflect this. That is, the desired outcome (for example, a new technology) generates its own definition. Add to this how individuals perceive innovation and one could create a definition for every innovation product, process, or service. Therefore, searching for a more unified approach to understanding innovation begins with the individual.

\section{INDIVIDUAL PERCEPTIONS OF INNOVATION}

Searching for a more unified definition of innovation begins with how individuals perceive innovation. The dynamics of innovation evolve around creativity, change, and improvement (given that much of recognized innovation is about making something better) (Zhuang, 1995). All three dynamic characteristics define innovation from a human perspective. An individual's ability to innovate is based on their knowledge, skills, and attitude (Zhuang, 1995, p. 15). They bring together these characteristics to initialize the innovation process. Zhuang (1995) created a10-item survey that measured how individuals understand innovation; what does innovation mean to each individual. Individuals evaluated each conceptual statement of innovation with their level of agreement or disagreement using a five-point Likert scale. A comparison of average responses for each question resulted in no identified statistical differences (Zhuang, 1995). Zhuang did encounter a diversity of responses, as exhibited in his pilot study (1995), causing the averages to test as insignificant. Zhuang (1995) found that the 10 statement means responses were indistinguishable. Given these results, Zhuang did not pursue any further, more sophisticated analysis. 
The result of Zhuang's (1995) study did indicate an outcome dependency for understanding innovation. In practical terms, people understand an innovation when they see or experience it. Zhuang's (1995) pilot study results led this researcher to the belief that individuals perceptions varied too greatly to validate the three-dimensional properties of innovation. Individual perceptions varied too greatly to justify statistical differences between the three elements of innovation. However, the perspective was to remain strictly at the individual level.

Given the recent literature on creativity and innovation, Chang, (2011); Girota, Terwiesch, and Ulrich ( 2010); Badke-Schaubm Goldschmidt, and Meijer, (2010); DeCusatis (2008) the emphasis has been on team performance rather than the individual. Creativity and innovation come from human knowledge and experience. Determining how individuals understand the concept of innovation would seem paramount before embarking on defining creative concepts and thinking. Rogers' Diffusion of Innovation Theory, "is a useful systemic framework to describe either adoption or non-adoption of new technology" (MacVaugh and Schiavone, 2010, p. 197). Adoption or slow adoption of any innovation may be due to social issues (McVaugh and Schiavone, 2010) which have a strong human component. Thus, the individual controls much of the success of an innovation project. Innovation flourishes when organizations appreciate their employees and place them in a supportive and creative environment (Zhuang, et al. (1999).

\section{ADVANCING THE RESEARCH}

McAdam and McClelland (2002) extended the research using Zhuang's definition of individual innovation. Their research focused on creativity generation at the individual and team levels. Three elements of creativity: expertise, creative thinking, and task motivation identify those components critical to innovation efforts. Research on the "source of ideas" (McAdam and McClelland, 2002, p. 95) remains limited and this limitation provides an opportunity for further studies, especially those that examine the source of ideas, i.e., individuals. Building on this information, Project Impact, a non-profit organization dedicated to innovation research, decided to use the Zhuang revised instrument (1995) to determine if a homogeneous group of respondents employed by various companies in the IT industry within the United States) perceived a similar concept of innovation using the Zhuang (1995; 1999) three-element perspective. Zhuang gave permission to use the survey. Zhuang (1999) has documented that validity and reliability for the instrument.

\section{SELECTION OF SAMPLE}

The primary author's familiarity with American Latino's and the IT Industry was the reason for choosing this population. Recent studies (Raffo, Lhuillery, and Miotti, 2008) that Latin American countries are more capable of transforming R\&D resources into innovation. In addition, the Raffo, et.al, (2008) study indicates that similarity exists between individuals with this ethnic background. Two reasons exist for choosing this group: 1. The IT Industry is a frequent generator of innovations, including those with a short life cycle; 2. Latino American's are a relatively homogeneous group that share many common perceptions and expectations.

\section{DATA ANALYSIS}

For this analysis, the authors chose only Zhuang's survey items (Appendix A) that describe how an individual understands innovation. Hypothesis testing will determine if there is a difference between the mean response for each statement as well as a test of homogeneity of variance of the responses to determine variability of the responses.

Ho1: There is no mean difference between the ten survey statement responses.

Ha1: There is a mean difference between the ten survey statement responses.

To test the 10-survey response means, the authors chose an Analysis of Variance (ANOVA) technique at the $95 \%$ confidence level. The IBM SPSS 19 software performed all the statistical analysis. 
Table I: ANOVA Analysis

\begin{tabular}{|l|c|c|c|c|c|}
\hline \multicolumn{1}{|c|}{ Response } & & & & & \\
\hline & Sum of Squares & df & Mean Square & F & Sig. \\
\hline Between & 2023.662 & 9 & 224.851 & 79.599 & .000 \\
\hline Within & 22005.105 & 7790 & 2.825 & & \\
\hline Total & 24028.767 & 7799 & & & \\
\hline
\end{tabular}

Sources: Project Impact

Unlike Zhuang's (1995) results, the statements tested to be statistically significant, as indicated in Table I.

These results and a statistically significant test of homogeneity of variances verify that individual responses vary when assessing different elements (meanings) of innovation. The authors conducted homogeneity of variance test at the $95 \%$ confidence level, as indicated in Table II.

Ho2: There are no differences in the variances between the 10 survey statement responses.

Ha2: There is a difference between the variances for the 10 survey statement responses.

Table II: Homogeneity of Variance test

\begin{tabular}{|c|c|c|c|}
\hline Levene Statistic & df1 & df2 & Sig. \\
\hline 14.188 & 9 & 7790 & .000 \\
\hline
\end{tabular}

Sources: Project Impact

The homogeneity of variances verifies that individual responses vary when assessing different elements (meanings) of innovation, as indicated in Table II. The Levene statistic reinforces that variation is different for different questions. The ANOVA statistic verifies what is obvious from the box-plot in Figure I. Outliers are the reason for the lack of homogeneity of variance, but these represent true responses and as such are included in the analysis. Figure I displays the overall box-plots (with outliers) for all 10 questions. The data exhibits both diversity and similarity of response between the 10 questions, reinforcing that individual perceptions do vary. As Zhuang (1995; 1999) predicted, there is a great deal of variation in the response, but the presence of statistically significant mean difference in the statements suggests further analysis. The purpose of the additional analysis is to determine if innovation consists of three unique components as the Zhuang (1995) definition suggests.

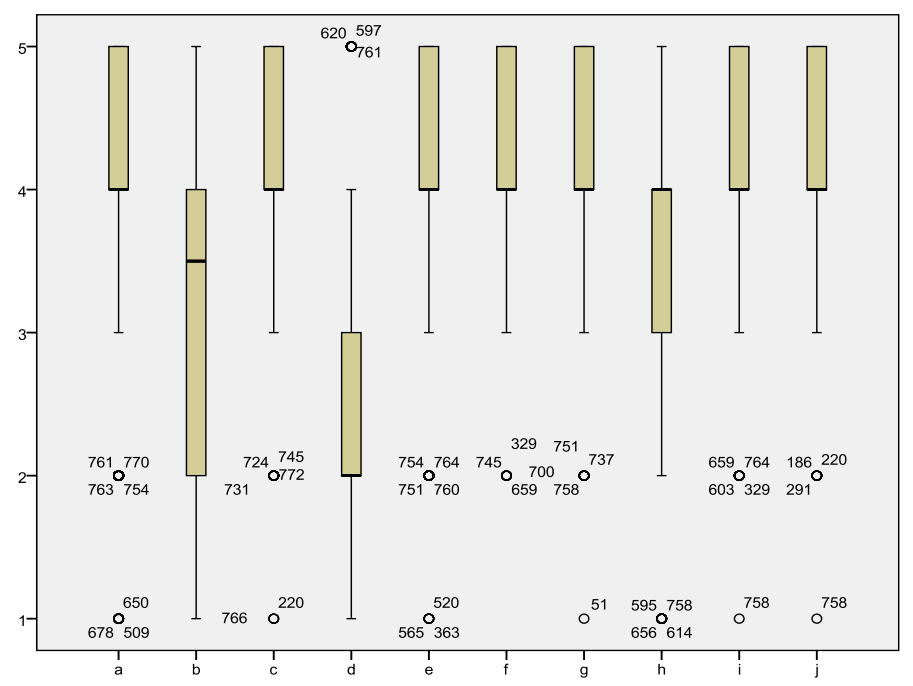

Figure I: Box-plots of Survey Responses for each question Source: Project Impact

The first set of techniques applied was factor analysis. "Factor analysis condenses (summarizes) information contained in number of original variables into a smaller set of new, composite dimensions or factors 
with a minimum loss of information" (Hair, Anderson, Tatham and Black, 1995, p. 368). Factor analysis, "searches for and defines fundamental constructs or dimensions assumed to underline the original variables" (Hair, et al., 1995, p. 368).

For this study, factor analysis will determine if the Zhuang $(1995,1999)$ three dimensions of an individual's understanding of innovation remains intact. Therefore, will the survey statements factor into a set of independent concepts (constructs) following the Zhuang dimensions? Second, will the factors explain a large portion of the extraneous variation, and thus considered as true descriptors of innovation at an individual level?

Following the direction and recommendations of Churchill (1979), the authors conducted additional analysis on validity and reliability of the Zhuang survey instrument. A factor analysis enables the researcher to determine what concepts come forth from the survey statements and whether these concepts are independent of one another. Factor analysis has three critical assumptions: normality of the data, linearity, and conceptual linkages (Hair, et al., 1995). The most important assumption is that a conceptual linkage exists. Given the large sample size, linearity of response, and definite conceptual linkages between the statements, the technique meets the requirements of the research intent. Given the need for uncorrelated (unique) factors, Varimax Rotation of the entire 781 survey responses yielded the following information. Results identified three independent factors (constructs) describing $57 \%$ of the total explained variation. Table III lists the factors and 10 statement (a-j) alignments.

Table III: Rotated Factor Loadings

\begin{tabular}{|l|c|c|c|}
\hline & Factor 1 & Factor 2 & Factor 3 \\
\hline Statements & $\mathrm{c}, \mathrm{e}, \mathrm{f}, \mathrm{g}, \mathrm{i}, \mathrm{j}$ & $\mathrm{d}, \mathrm{h}$ & $\mathrm{a}, \mathrm{b}$ \\
\hline Naming Convention & Improvement/change & Adopting what has existed previously & New ideas or something new \\
\hline
\end{tabular}

Source: Project Impact

Following Zhuang (1995; 1999) results, a three-factor solution compares well with the definition of individual innovation except for slight differences in the naming conventions and probable statement alignment (new or something new) is a third factor rather than a first factor, as proposed by Zhuang $(1995 ; 1999)$. However, the fact that the data only describes $57 \%$ of the explained variation is significant. For the social sciences, $60 \%$ or less explained variation is satisfactory (Hair, et al., 1995). Although the data meets these criteria, a more detailed analysis of the data (identifying characteristics of individuals) could reveal a better-developed relationship. Additionally, the Kaiser-Meyer-Olkin measure of sample adequacy (.764 - a very adequate result) and Bartlett's test of sphericity are statistically significant $(\mathrm{p}<.001)$, confirming correlations among the 10 survey statements. Finally, an alpha reliability estimate of .675 verifies a small amount of inconsistency in the data, but proves acceptable as a measure of overall survey reliability. To confirm the factor model, the authors used a split sample analysis (Hair, et al., 1995). For the split sample method, only statement "e" (Appendix A) moves from Factor 1 to Factor 2; it does not influence the naming convention; and the explained variation $(57.5 \%)$ and; as with the full sample, the KeiserMeyer-Olkin and Bartlett's tests are significant and nearly equal to the original values. This confirms the general association of statements to factors.

\section{Further Analysis}

Often in situations where the factor analysis does not provide complete results, statisticians recommend examining the data in finer detail. One such method, "Q factor analysis" bases the analysis on distinguishing individual respondent characteristics, such as demographic variables (Hair, et al., 1995). Selecting demographic variables provides a method of selecting the data to include only the identified classification. In general, demographic variables such gender, age, position, function, etc. help to identify a more homogeneous group. These groups would more than likely contain like-minded individuals who would perceive innovation in a similar manner. The authors used three demographic characteristics (gender, function and age as identified by Generation) to examine the survey statements and responses.

No pronounced gender differences exist between the three identified constructs associated with the factor analysis. Both analyses describe approximately $58 \%$ of the explained variation, have acceptable Keseir- MeyerOlkin (.74 versus .75) statistics, with Bartlett's test of sphericity statistically significant $(p<.001)$. The only 
difference is that statement " $\mathrm{c}$ " (improving something that already exists) aligns with factor 2 for Male respondents. Both genders can identify three unique and specific elements of innovation. Even though only one statement varied between the genders, further analysis separates gender related effects.

The second demographic variable was job function. The authors subdivided this variable into two groups those who identified themselves as holding a technical position and those who did not. Traditionally, creativity and innovation were associated with $R \& D$, IT and engineering departments. Recent thinking suggests that innovation must occur at all levels in the organization, unleashing employee creativity (Dobni, 2008). Therefore, we sorted the data by gender for technical from non-technical people to determine if perceptions were distinctive.

From the original data source and subsequent classifications, the authors conducted an ANOVA test of factor means to determine statistical significance at the $95 \%$ confidence level, as described in Table IV.

Table IV: Female Non-technical Respondents

\begin{tabular}{|l|l|l|l|l|c|c|c|}
\hline \multicolumn{1}{|c|}{ Factor } & \multicolumn{1}{|c|}{$\mathbf{1}$} & \multicolumn{1}{c}{$\mathbf{2}$} & $\mathbf{2}$ & Explained Var. & KMO & Bartlett & Alpha \\
\hline Statements & $\mathrm{c}, \mathrm{f}, \mathrm{g}, \mathrm{i}, \mathrm{j}$ & $\mathrm{d}, \mathrm{e}, \mathrm{h}$ & $\mathrm{a}, \mathrm{b}$ & $57 \%$ & 0.75 & $<.001$ & 0.67 \\
\hline Naming & $\begin{array}{l}\text { Improve or } \\
\text { Change }\end{array}$ & $\begin{array}{l}\text { Adopt traits } \\
\text { of successful } \\
\text { people }\end{array}$ & $\begin{array}{l}\text { Generating or } \\
\text { inventing } \\
\text { new ideas }\end{array}$ & $\begin{array}{l}\text { Factor Means: F1= 4.36; F2=3.34; F3=3.48 } \\
\text { ANOVA, significant at } \mathrm{p}<.001\end{array}$ \\
\hline
\end{tabular}

Source: Project Impact

Ho3: $\quad$ Mean of Factors 1, 2, and 3 are not statistically different

Ha3: at least one Factor mean is different

To test the hypothesis for the original source data, the authors selected an ANOVA analysis. For Latino females with a non-technical job function, respondents scored Factor 1 as those statements that they most agree with regarding their understanding of innovation. Statistical differences exist between the statements that constitute each factor (differences between Factor 1 and Factors 2 and 3).

Table V: Female Technical Respondents

\begin{tabular}{|l|l|l|l|l|l|c|c|}
\hline \multicolumn{1}{|c|}{ Factor } & \multicolumn{1}{c|}{$\mathbf{1}$} & \multicolumn{1}{c|}{$\mathbf{2}$} & $\mathbf{2}$ & Explained Var. & KMO & Bartlett & Alpha \\
\hline Statements & $\mathrm{c}, \mathrm{f}, \mathrm{g}, \mathrm{i}, \mathrm{j}$ & $\mathrm{d}, \mathrm{h}$ & $\mathrm{a}, \mathrm{b}$ & $75 \%$ & 0.65 & $<.001$ & 0.73 \\
\hline Naming & $\begin{array}{l}\text { Improve or } \\
\text { Change to } \\
\text { new }\end{array}$ & $\begin{array}{l}\text { Adopt traits } \\
\text { of market } \\
\text { leader }\end{array}$ & $\begin{array}{l}\text { Generating or } \\
\text { inventing } \\
\text { new ideas }\end{array}$ & $\begin{array}{l}\text { Factor Means: F1=4.31; F2=3.07; F3=3.38 } \\
\text { ANOVA, significant at } \mathrm{p}<.001\end{array}$ \\
\hline
\end{tabular}

Source: Project Impact

Slight differences exist between technical and non-technical females, as indicated in Table $\mathrm{V}$ who participated in the study, both in the alignment of statements to a particular factor and with the naming convention. The means for Factor 3 are essentially identical for all the Female data. Factor 1 means are quite close except for statement "e" that aligns with Factor 2 for female non-technical personnel. Again, statistical differences exist between Factor 1 and Factors 2 and 3. A great deal of consistency does exist between the Latino female data for technical and non-technical workers. Given the reduction in the expected overall percentage of explained variation, other classifying or categorizing variables may provide more detail and a better fit of the factors to the data.

As this is exploratory, naming the factors is less important than observing how statements align. The three factors do align well with the Zhuang $(1995,1999)$ perspective (definition of innovation), verifying that innovation is a multidimensional construct. Of course, explained variation is still below desired limits (approximately 70\%), but meets guidelines for social research. The lower than desired explained variation could suggest that other variables (classifications) may be influential to the analysis or that sample sizes are an issue when categorizing the data. The similarities between job function are greater than expected. For the women surveyed, differences in perceptions are small when segregating for technical versus non-technical. Reliability statistics (Coefficient Alpha) confirm a moderate consistency of response. 
For male respondents, a very different pattern emerges, as indicated in Table VI and Table VII. Technical individuals understand that innovation occurs when identifying the best new ideas, and/or best people, while Nontechnical males want to attract the best people or improve those that are available internally. As with the Female data, when statements " $\mathrm{i}$ " and " $\mathrm{j}$ " are scored, the average agreement is much higher. Again, statements "a" and "b" align together, but with a smaller average agreement level than Factor 1. For the males, statements "a "and "b", "i" and " $\mathrm{j}$ ", and "c" and "d", are scored similarly. This only reinforces that an understanding of innovation is truly multi-dimensional.

Table VI: Male Non-technical Respondents

\begin{tabular}{|c|l|l|l|l|l|c|c|}
\hline Factor & \multicolumn{1}{|c|}{$\mathbf{1}$} & \multicolumn{1}{c}{$\mathbf{2}$} & $\mathbf{2}$ & Explained Var. & KMO & Bartlett & Alpha \\
\hline Statements & $\mathrm{c}, \mathrm{d}, \mathrm{e}, \mathrm{f}, \mathrm{h}$ & $\mathrm{g}, \mathrm{i}, \mathrm{j}$ & $\mathrm{a}, \mathrm{b}$ & $53 \%$ & 0.73 & $<.001$ & 0.59 \\
\hline Naming & $\begin{array}{l}\text { Improve or } \\
\text { Attract the } \\
\text { best people }\end{array}$ & $\begin{array}{l}\text { Change to a } \\
\text { different } \\
\text { perspective }\end{array}$ & $\begin{array}{l}\text { Generating or } \\
\text { inventing } \\
\text { new ideas }\end{array}$ & $\begin{array}{l}\text { Factor Means: F1=3.72; F2=4.34; F3=3.53 } \\
\text { ANOVA, significant at } \mathrm{p}<.001\end{array}$ \\
\hline
\end{tabular}

Source: Project Impact

Table VII: Male Technical Respondents

\begin{tabular}{|c|l|l|l|l|c|c|c|}
\hline Factor & \multicolumn{1}{|c|}{$\mathbf{1}$} & \multicolumn{1}{c}{$\mathbf{2}$} & $\mathbf{2}$ & Explained Var. & KMO & Bartlett & Alpha \\
\hline Statements & $\mathrm{e}, \mathrm{f}, \mathrm{g}, \mathrm{i}, \mathrm{j}$ & $\mathrm{a}, \mathrm{b}$ & $\mathrm{c}, \mathrm{d}, \mathrm{h}$ & $61 \%$ & 0.73 & $<.001$ & 0.70 \\
\hline Naming & $\begin{array}{l}\text { Improve or } \\
\text { Change to } \\
\text { new }\end{array}$ & $\begin{array}{l}\text { Adopt traits } \\
\text { of market } \\
\text { leader }\end{array}$ & $\begin{array}{l}\text { Generating or } \\
\text { inventing } \\
\text { new ideas }\end{array}$ & $\begin{array}{l}\text { Factor Means: F1= 4.32; F2=3.68; F3=3.45 } \\
\text { ANOVA, significant at } \mathrm{p}<.001\end{array}$ \\
\hline
\end{tabular}

Source: Project Impact

Examined in the context of agreement scoring there is a possible perceptual divide between men and women in different job functions. Of course, the results are exploratory not confirmatory. The message for practitioners is that managers or leaders of any organization should expect differences in individual perceptions and the consequences that follow because of these differences. This begins to confirm the assertion that individual perceptions of innovation vary among specific demographic groups. Migliore (2011) found that occupational job categories show a high degree of individualism. Individualism is Hofstede's cultural variable (Minkov and Hofstede, 2011, p. 12) that defines the relationship between the individual and the group that in this case is the functional position. Given the dimensionality of innovation, different understandings of innovation could become an obstacle for group alignment. Certainly differing perceptions between individuals result in miscommunication, inefficiency, and lost opportunity.

Finally, the authors applied the last demographic variable, age, classified by Generational labels Gen Y, Gen X, Baby Boomers. (Gen Y- ages between 18-30 years old; Gen X - 31-44; Baby Boomers - 45 and older. "Putting a group of strangers together, side-by-side is bound to cause conflict; now mix individuals from different generation and watch the conflict multiply" (Houlihan, 2007, p. 10). According to Kapoor and Solomon (2011), employers must identify separate characteristics of each generation (p. 308) and use these unique characteristics to improve diversity and create a productive work environment. One such characteristic that has been widely researched is that of generational differences. Differences in attitudes, values, and work styles characterize the generations (Piktialis, 2004, p.38). Each generation brings in a difference in their modalities of communication (Glass, 2007) Baby Boomers prefer face-to-face contact and Gen Y is comfortable with e-mails, instant messaging and texting. Generations could have difficulty expressing their perceptions of innovation, thus increasing efforts of management to align perceptions to a common understanding.

Therefore, generational differences between gender and function provide further evidence that differences in perceptions exist and like groups share a similar understanding of innovation. Before examining this level of detail, the authors generated a hypothesis to test if the three-way interaction of gender, function, and generation is significant. If the interaction tests to be statistically significant, then a separate evaluation of generational differences (as a standalone variable) is warranted. The dependent variable is each of the 10-statement response and the independent variable is the gender, functional and the generational interaction. 
Ho3: There is no difference between the interaction of gender, function and generation and the 10 survey statement mean responses.

Ha3: There is a difference between the interaction of gender, function and generation and the 10 survey statement mean responses.

Table VIII - Multivariate ANOVA analysis

\begin{tabular}{|l|l|c|c|c|c|c|}
\hline \multicolumn{1}{|c|}{ Effect } & \multicolumn{1}{c|}{ Test } & Value & F & Hypothesis df & Error df & Sig. \\
\hline $\begin{array}{l}\text { Gender } \\
\text { Function* } \\
\text { Generation }\end{array}$ & Pillai's Trace & .056 & 1.605 & 20.000 & 1120.000 & .044 \\
\hline & Wilks' Lambda & .945 & $1.603^{\mathrm{a}}$ & 20.000 & 1118.000 & .045 \\
\hline & Hotelling's Trace & .057 & 1.601 & 20.000 & 1116.000 & .045 \\
\hline & Roy's Largest Root & .034 & $1.927^{\mathrm{b}}$ & 1.0000 & 560.000 & .039 \\
\hline
\end{tabular}

Source: Project Impact

A multivariate ANOVA of the 10 questions and the 3 characteristics of gender, function, and generation tested to be statistically significant at the $95 \%$ confidence level. This analysis, as confirmed in Table VIII) confirms that the interaction categorizes individuals by gender, function and generational cohort is statistically significant. The practical significance is that individuals do vary in their understanding of innovation, and that certain groups share similar perceptions. Appendices B-E contains a summary of the Factor Analysis for the three-way interaction results by generation. Appendices B - E detail gender by function and by generation. Mean response scores for each factor use an ANOVA technique to compare differences. The most surprising result is the difference in statement alignment for Gen Y. The rapid adoption of technology may explain how Generation Y understands innovation and the fact that improvements or changes are interchangeable with new inventions. The older generations seem to favor the three-element model more effectively. Appendix F summarizes the results. Further study needs to explain these differences.

Normally, a three-way interaction has limited predictive influence except for the fact that the demographic categories do test to be dependent on one another. This is a significant result, in that individual perceptions may align with a person's gender, functional background (technical versus non-technical) and/or generational cohort. The three-way interaction demonstrates how perceptions vary, especially between generations and how complicated and confounding it is to reach a level of understanding between individuals. Yet, many continue to believe that innovation is simply a new idea or invention; they do not understand its complexity. Misunderstanding the dimensionality of innovation could result in failed attempts and less than desired results. Realizing its implications from an individual perspective, selecting individuals with a similar understanding of innovation would improve alignment to project objectives and both efficiency and effectiveness.

\section{CONCLUSION}

Innovation, as understood by the sample of individuals in an innovation-intensive industry, is a multidimensional construct. The data identified three distinctive dimensions of innovation. With some variation, patterns emerged for understanding innovation from a group of individuals who are familiar with rapid changes and new technology in their industry. The results highlight that understanding how individuals perceive innovation is not one-dimensional or simple. Definitions that limit innovation to creative activity, novel ideas or inventions severely restrict its meaning and its overall effectiveness. Even well intentioned organizations have reported that innovation efforts, when focused on the more traditional approach of idea generation as innovation, have succeeded only $10 \%$ of the time after 3 years (Dahl, Lawrence, and Pierce, 2011). Rather, expanding innovation efforts beyond ideas and novel improvements to strategies such as Lean Six Sigma or Change Management practices produce truly innovative outcomes. Ignoring the dimensionality of innovation reduces its overall influence and success. Realizing that innovation begins at the human level is critical for success. Innovation is difficult to accomplish unless its proponents can convince others to support their activities (Shane, 1994, p. 30). Aligning how individuals understand innovation is a key to their support and commitment. According to Gee and Gee (2011), every person has influence on his/her organization through their actions and behaviors. If everyone perceives innovation in a slightly different manner and no alignment of perceptions occurs, innovation efforts will produce little or no success. Innovation 
teams, which have been a catalyst for innovation projects (DeCusatis, 2008) have experienced problems when participants lack a clear and cohesive understanding of innovation. Although this study examined a relatively cohesive group, all within the same industry, validating differences in individual perceptions across a set of standard demographic characteristics. Multiply this affect with the global workforce that brings with it a set of diverse understandings, beliefs and value systems that all affect innovation (Caraballo, et al., 2011). Isolated or discrete events do not foster innovation, but rather a series of activities aligned with a unified purpose do foster innovation. Given its expanded definition, innovation's role is more organic than directed within the organization. Perceptions of innovation need alignment or a method devised to select individuals with a similar understanding of innovation.

\section{LIMITATIONS}

As with any exploratory study, limitations exist due to the identified population and sample. The authors chose a target population of Latino Americans, associated with numerous businesses within the IT industry, as an industry associated with constant innovations (new products and new technology). Respondents were expected to have a more refined and distinctive understanding of innovation. The results are not transferable to all individuals, but would be common to those who experience innovation on a more frequent basis. The research demonstrated that innovation understand by individuals, shares both common and complex components. In addition, as with all surveys, outliers may affect calculations of the mean. In this case, we accept the outliers as demonstrations that an individuals' understanding does not fit a prescribed set of definitions and that the variance in response is natural and expected.

\section{RECOMMENDATIONS}

We recommend further research on understanding innovation from a more diverse group of individuals. Given the diversity of response and presence of outliers in the data, we would recommend a revised survey that creates three specific groups of statements related to the concepts of "new, improved and change" to verify that these are, in fact, the three constructs that define innovation. Those responsible for conducting or managing innovation should value the perceptions of all team members, as well as be aware that a single definition may not apply to every project deemed innovative. Aligning individuals with similar perceptions will increase productivity and overall innovation project success.

\section{AUTHOR INFORMATION}

Dr. Ervin L. "Vinny" Caraballo is the President of Global Targeting. His has helped companies expand and improve operations through business development strategy, global sourcing, applying innovation, and leveraging resources on a global scale. He has advised clients in the USA, Singapore, Latin America, and India. His expertise spans several global technology and consulting firms. He is a US Army Aviation Officer. His educational achievements include a Doctorate in International Business from Nova Southeastern University, an MBA from Webster University, a Masters Certificate in Project Management from George Washington University, and a BA from Inter-American University of Puerto Rico. Ervin. L. Caraballo, Ph.D., CENTRUM Catolica, Lima Peru, 233 S. Wacker Drive, 84 ${ }^{\text {th }}$ Floor, Chicago, IL 60606 USA. E-mail: ecaraballo@eucp.edu.pe

Dr. Greg McLaughlin is Sr. Vice President, Research, and Development at Global Targeting. Greg brings a broad set of research and practical expertise on Innovation strategy, deployment, and lasting success. He held Executive positions at Reynolds Metals Company, Inthesis, Inc. and ADT Security Systems. Greg has international business advisory and instructional experiences. His educational achievements include a Doctorate in Business Administration from Nova Southeastern University, a Master of Science degree in Statistics from the Florida State University and an undergraduate degree in Meteorology from the Florida State University. Greg is one of only a few Senior Master Black Belts. Gregory C. McLaughlin, Ph.D., Capella University, Minneapolis, MN, 3080 NE $47^{\text {th }}$ Court \#308, Fort Lauderdale, FL 33308 USA. E-mail: gregory.mclaughlin@ capella.edu (Corresponding author) 


\section{REFERENCES}

1. Badke-Schaub, P. Goldschmidt, G. and Meijer, M. (2010), "How does cognitive conflict in design teams support the development of ideas?", Creativity and Innovation Management, 19, 2, pp. 119-133.

2. Baregheh, A., Rowley, J. and Sambrook, S. (2009), "Towards a multidisciplinary definition of Innovation", Management Decision, 47(8), 1323-1339.

3. Caraballo, E., Bynum, T. and McLaughlin, G. (2011), "How to foster innovation in BPO", Globalization Today, July-August, pp. 28-33.

4. Chang, C. (2011), "New organizational designs for promoting creativity: A case study of virtual teams with anonymity and structured interactions", Journal of Engineering and Technology Management, 28, 4, pp. 268-282.

5. Churchill, G. (1979), “A paradigm for developing better measures of marketing constructs”, Journal of Market Research, 16,1, 1979 pp. 64-73.

6. DeCusatis, C. (2008), "Creating, growing and sustaining efficient innovation teams", Creativity and Innovation Management, 12, 2, pp. 155-164.

7. deWaal, A., Maritz, A. and Shieh, C. (2010), "Managing innovation: A typology of theories and practicedbased applications for New Zealand firms", International Journal of Innovation Organization, 3, 2(Fall, 2010), pp.35-57.

8. Dahl, A, Lawrence, J., and Pierce, J. (2011), "Building an innovation community", Research - Technology Management, September-October, pp. 19-27.

9. Dobni, C. (2008), "The DNA of innovation", Journal of Business Strategy, 29, 2, pp.43-50.

10. Flight, R., Allaway, A., Kim, W. and D'Souza, G. (2011), “A study of perceived innovation characteristics across cultures and stages of diffusion", Journal of Marketing Theory and Practice, 19, 1, pp.109-125.

11. Gee, V. and Gee, S. (2011), "Business improve creates a culture of change and innovation", Journal for Quality and Participation, 34, 3, pp. 30-33.

12. Glass, A. (2007), “Understanding generational differences for competitive success", Industrial and Commercial Training, 39, 2 pp. 98-103.

13. Girotra, K., Terwiesch, C. and Ulrich, K. (2010), "Idea generation and the quality of the best idea", Management Science, 54, 4, pp. 591-605.

14. Hair, J., Anderson, R., Tatham, R. and Black, W. (1995), Multivariate Data Analysis: Fourth Edition, Prentice Hall: Englewood Cliffs.

15. Houlihan, A. (2007), "The new melting pot: how to effectively lead different generations in the workplace, SuperVision, 68, 9, pp. 10-12.

16. Kapoor, C., and Solomon, N. (2011), "Understanding and managing generational differences in the workplace", Worldwide Hospitality and Tourism Themes", 3, 4, pp. 308-314.

17. MacVaugh, M. and Schiavone, F. (2010), "Limits to the diffusion of innovation: A literature review and integrative model", European Journal of Innovation Management, 13, 2, pp. 197-211.

18. McLaughlin, H., McLaughlin, G., and Presiosi, R.C. (2004). The relationship of learning orientation to organizational performance, Journal of Business and Economics Research,2(4), 9-16.

19. McAdam, R. and McClelland, J. (2002), Individual and team-based idea generation within innovation management: organisational and research agendas", European Journal of Innovation Management, 5, 2, pp. 86-97.

20. Migliore, L. (2011), "Relation between big five personality traits and Hofstede's cultural dimensions", Cross Cultural Management: An International Journal, 18, 1, pp. 38-54.

21. Minkoc, M. and Hofstede, G. (2011), "The evolution of Hofstede's doctrine", Cross Cultural Management: An International Journal, 18, 1, pp. 10-20.

22. Piktialis, D. (2004), "Bridging generational divides to increase innovation, creativity and productivity", Workspan, 47, 8, pp. 36-41.

23. Raffo, J., Lhuillery, S., and Miotti, L., (2008). "Northern and southern innovativity: a comparison across European and Latin American countries", The European Journal of Development Research, 20, 2, pp. 219 239.

24. Shane, S. (1994), "Championing Innovation in the Global Corporation", Research Technology Management, 37, 4, 29-35. 
25. Spence, W. (1994), Innovation - the communication of change in ideas, practices and products, Chapman and Hall, London.

26. Thompson, V. (1965), "Bureaucracy and innovation”, Administrative Science Quarterly, 10, pp. 1-20.

27. Wang, S., Guidice, R., Tansky, J. and Wang, Z. (2010), "When R\&D spending is not enough: The critical role of culture when you really want to innovate", Human Resource Management, 49, 4, pp. 767-792.

28. Zhuang, L. (1995), "Bridging the gap between technology and business strategy: A pilot study on the innovation process", Management Decision, 33, 8, pp. 13-19.

29. Zhuang, L., Williamson, D. and Carter, M. (1999), "Innovate or liquidate - are all organizations convinced? A two-phased study into the innovation process", Management Decisions, 37, 1, pp. 57-71. 


\section{APPENDIX A}

\section{Survey Statements}

A - Inventing something entirely new

B - Generating new ideas only

C- Improve something that already exists

D - Follow the market leader

E - Attracting Innovative people

$\mathrm{F}$ - Performing an existing task a new way

$\mathrm{G}-$ Spreading new ideas

$\mathrm{H}$ - Adopting something that has been tried elsewhere

I - Seeing something from a different perspective

J - Introducing Change

\section{APPENDIX B}

Latino Females - Technical by Generation

Generation Y

\begin{tabular}{|c|c|c|c|c|c|c|c|}
\hline Factor & 1 & 2 & 3 & Explained Var. & $\mathrm{KMO}$ & Bartlett & Alpha \\
\hline Statements & $b, e, f, i, j$ & $\mathrm{c}, \mathrm{d}, \mathrm{g}, \mathrm{h}$ & $\mathrm{a}$ & $73 \%$ & 0.52 & $<.001$ & 0.70 \\
\hline Naming & $\begin{array}{l}\text { Change and } \\
\text { new } \\
\text { perspectives }\end{array}$ & $\begin{array}{l}\text { Adopting what's } \\
\text { best from others }\end{array}$ & New ideas & \multicolumn{4}{|c|}{$\begin{array}{l}\text { Factor Means: } \mathrm{F} 1=4.06 ; \mathrm{F} 2=3.74 ; \\
\mathrm{F} 3=3.90 \\
\text { ANOVA not significant at } \mathrm{p}=.58\end{array}$} \\
\hline
\end{tabular}

Source: Project Impact

Generation X

\begin{tabular}{|c|c|c|c|c|c|c|c|}
\hline Factor & 1 & 2 & 3 & Explained Var. & KMO & Bartlett & Alpha \\
\hline Statements & $\mathrm{f}, \mathrm{g}, \mathrm{i}, \mathrm{j}$ & $\mathrm{a}, \mathrm{d}, \mathrm{e}, \mathrm{h}$ & $\mathrm{b}, \mathrm{c}$ & $75 \%$ & 0.62 & $<.001$ & 0.77 \\
\hline Naming & $\begin{array}{c}\text { Doing tasks a } \\
\text { different way }\end{array}$ & $\begin{array}{c}\text { Invent or borrow } \\
\text { from the leader }\end{array}$ & $\begin{array}{c}\text { something new } \\
\text { or adopt the } \\
\text { best }\end{array}$ & $\begin{array}{c}\text { Factor Means: } \mathrm{F} 1=4.47 ; \mathrm{F} 2=3.61 ; \mathrm{F} 3=3.57 \\
\text { ANOVA significant at } \mathrm{p}<.001\end{array}$ \\
\hline
\end{tabular}

Source Project Impact

Baby Boomers (note sample sizes too small for Analysis)

Source: Project Impact 


\section{APPENDIX C}

Latino Females - Non-Technical by Generation

Generation Y

\begin{tabular}{|c|c|c|c|c|c|c|c|}
\hline Factor & 1 & 2 & 3 & Explained Var. & $\mathrm{KMO}$ & Bartlett & Alpha \\
\hline Statements & $e, f, g, i, j$ & $a, b$ & $\mathrm{c}, \mathrm{h}$ & $56 \%$ & 0.66 & $<.001$ & 0.58 \\
\hline Naming & $\begin{array}{l}\text { Improve or } \\
\text { change }\end{array}$ & $\begin{array}{c}\text { Generating or } \\
\text { inventing new } \\
\text { ideas }\end{array}$ & $\begin{array}{c}\text { Improving } \\
\text { something that } \\
\text { exists }\end{array}$ & \multicolumn{4}{|c|}{$\begin{array}{l}\text { Factor Means: } \mathrm{F} 1=4.3 ; \mathrm{F} 2=3.58 ; \mathrm{F} 3=3.46 \\
\text { ANOVA significant at } \mathrm{p}<.001\end{array}$} \\
\hline
\end{tabular}

Source: Project Impact

Generation X

\begin{tabular}{|c|c|c|c|c|c|c|c|}
\hline Factor & 1 & 2 & 3 & Explained Var. & $\mathrm{KMO}$ & Bartlett & Alpha \\
\hline Statements & $c, f, g, i, j$ & $\mathrm{~d}, \mathrm{e}, \mathrm{h}$ & $\mathrm{a}, \mathrm{b}$ & $60 \%$ & 0.73 & $<.001$ & 0.70 \\
\hline Naming & $\begin{array}{l}\text { Improve or } \\
\text { change }\end{array}$ & $\begin{array}{c}\text { Generating or } \\
\text { inventing new } \\
\text { ideas }\end{array}$ & $\begin{array}{c}\text { Generating or } \\
\text { inventing new } \\
\text { ideas }\end{array}$ & \multicolumn{4}{|c|}{$\begin{array}{l}\text { Factor Means: } \mathrm{F} 1=4.34 ; \mathrm{F} 2=3.30 ; \mathrm{F} 3=3.41 \\
\text { ANOVA significant at } \mathrm{p}<.001\end{array}$} \\
\hline
\end{tabular}

Source: Project Impact

Baby Boomers

\begin{tabular}{|c|c|c|c|c|c|c|c|c|}
\hline Factor & 1 & 2 & 3 & Explained Var. & KMO & Bartlett & Alpha & Factor 4 \\
\hline Statements & $\mathrm{e}, \mathrm{f}, \mathrm{g}$ & $\mathrm{c}, \mathrm{d}, \mathrm{h}$ & $\mathrm{i}, \mathrm{j}$ & $72 \%$ & 0.59 & $<.001$ & 0.69 & $\mathrm{a}, \mathrm{b}$ \\
\hline Naming & $\begin{array}{c}\text { Actively } \\
\text { seeking new } \\
\text { people or ideas }\end{array}$ & $\begin{array}{c}\text { Improve or try } \\
\text { something that } \\
\text { exists }\end{array}$ & $\begin{array}{c}\text { Changing } \\
\text { Perspectives }\end{array}$ & $\begin{array}{l}\text { Factor Means: } \mathrm{F} 1=4.25 ; \mathrm{F} 2=3.52 ; \mathrm{F} 3=4.45 ; \\
\text { ANOVA significant at } \mathrm{p}<.001\end{array}$ & $\begin{array}{c}\text { Generating } \\
\text { or inventing } \\
\text { new ideas }\end{array}$ \\
\hline
\end{tabular}

Source: Project Impact 


\section{APPENDIX D}

Latino Males - Technical by Generation

\begin{tabular}{|c|c|c|c|c|c|c|c|}
\hline \multicolumn{8}{|c|}{ Generati } \\
\hline Factor & 1 & 2 & 3 & Explained & $\mathrm{KMO}$ & Bartlett & Alpha \\
\hline Statements & $c, f, g, j$ & $b, e, i$ & $\mathrm{a}, \mathrm{d}, \mathrm{h}$ & $70 \%$ & 0.52 & 0.045 & 0.76 \\
\hline Naming & $\begin{array}{c}\text { Improve or } \\
\text { Change }\end{array}$ & $\begin{array}{l}\text { New people } \\
\text { bring new } \\
\text { perspectives }\end{array}$ & $\begin{array}{l}\text { Invent or } \\
\text { borrow from } \\
\text { the leader }\end{array}$ & \multicolumn{4}{|c|}{$\begin{array}{l}\text { Factor Means: } \mathrm{F} 1: 4.45 ; \mathrm{F} 2=3.9 ; \\
\mathrm{F} 3=3.2 \\
\text { ANOVA significant at } \mathrm{p}<.001\end{array}$} \\
\hline
\end{tabular}

Source: Project Impact

Generation X

\begin{tabular}{|c|c|c|c|c|c|c|c|}
\hline Factor & 1 & 2 & 3 & $\begin{array}{c}\text { Explained } \\
\text { Var. }\end{array}$ & KMO & Bartlett & Alpha \\
\hline Statements & $\mathrm{e}, \mathrm{f}, \mathrm{g}, \mathrm{i}, \mathrm{j}$ & $\mathrm{b}, \mathrm{c}, \mathrm{d}$ & $\mathrm{a}, \mathrm{h}$ & $56 \%$ & 0.69 & $<.001$ & 0.59 \\
\hline Naming & $\begin{array}{c}\text { Improve or } \\
\text { change } \\
\text { or follow the } \\
\text { leader }\end{array}$ & $\begin{array}{c}\text { Generate new } \\
\text { something } \\
\text { the best }\end{array}$ & $\begin{array}{l}\text { Factor Means: } \mathrm{F} 1=4.28 ; \mathrm{F} 2=3.43 \\
\mathrm{~F} 3=3.77 \\
\text { ANOVA significant at } \mathrm{p}<.001\end{array}$ \\
\hline
\end{tabular}

Source: Project Impact

Baby Boomer (Samples Sizes too small for adequate analysis) 


\section{APPENDIX E}

Latino Males - Non-Technical by Generation

Generation Y

\begin{tabular}{|c|c|c|c|c|c|c|c|}
\hline Factor & 1 & 2 & 3 & $\begin{array}{l}\text { Explained } \\
\text { Var. }\end{array}$ & KMO & Bartlett & Alpha \\
\hline Statements & $c, d, e, f, h$ & $\mathrm{~g}, \mathrm{i}, \mathrm{j}$ & $\mathrm{a}, \mathrm{b}$ & $66 \%$ & 0.58 & $<.001$ & 0.58 \\
\hline Naming & $\begin{array}{l}\text { Improving or } \\
\text { hiring best } \\
\text { people }\end{array}$ & $\begin{array}{l}\text { change to a } \\
\text { different } \\
\text { perspective }\end{array}$ & $\begin{array}{l}\text { Generating or } \\
\text { inventing new } \\
\text { ideas }\end{array}$ & \multicolumn{4}{|c|}{$\begin{array}{l}\text { Factor Means: } F 1=3.82 ; F 2=4.49 ; F 3=3.6 \\
\text { ANOVA, sgnificant at } \mathrm{p}<.001\end{array}$} \\
\hline
\end{tabular}

Source: Project Impact

Generation X

\begin{tabular}{|c|c|c|c|c|c|c|c|}
\hline Factor & 1 & 2 & 3 & $\begin{array}{c}\text { Explained } \\
\text { Var. }\end{array}$ & $\mathrm{KMO}$ & Bartlett & Alpha \\
\hline Statements & $\mathrm{g}, \mathrm{h}, \mathrm{i}, \mathrm{j}$ & $\mathrm{c}, \mathrm{d}, \mathrm{e}, \mathrm{f}$ & $\mathrm{a}, \mathrm{b}$ & $55 \%$ & 0.65 & $<.001$ & 0.62 \\
\hline Naming & $\begin{array}{l}\text { change to a } \\
\text { different } \\
\text { perspective }\end{array}$ & $\begin{array}{l}\text { Improving or } \\
\text { hiring best } \\
\text { people }\end{array}$ & $\begin{array}{l}\text { Generating or } \\
\text { inventing new } \\
\text { ideas }\end{array}$ & \multicolumn{4}{|c|}{$\begin{array}{l}\text { Factor Means: } \mathrm{F} 1=4.05 ; \mathrm{F} 2=3.56 ; \mathrm{F} 3=3.67 \\
\text { ANOVA, significant at } \mathrm{p}<.001\end{array}$} \\
\hline
\end{tabular}

Source: Project Impact

"Baby Boom" Generation

\begin{tabular}{|c|c|c|c|c|c|c|c|}
\hline Factor & 1 & 2 & 3 & $\begin{array}{c}\text { Explained } \\
\text { Var. }\end{array}$ & KMO & Bartlett & Alpha \\
\hline Statements & $\mathrm{e}, \mathrm{f}, \mathrm{g}, \mathrm{i}, \mathrm{j}$ & $\mathrm{a}, \mathrm{b}$ & $\mathrm{c}, \mathrm{d}, \mathrm{h}$ & $77 \%$ & 0.69 & $<.001$ & 0.77 \\
\hline Naming & $\begin{array}{c}\text { Improve or } \\
\text { change }\end{array}$ & $\begin{array}{c}\text { Generating or } \\
\text { inventing new } \\
\text { ideas }\end{array}$ & $\begin{array}{c}\text { Improve or } \\
\text { adopt the best }\end{array}$ & $\begin{array}{c}\text { Factor Means: } \mathrm{F} 1=4.34 ; \mathrm{F} 2=3.3 ; \mathrm{F} 3=3.5 \\
\text { ANOVA, significant at } \mathrm{p}<.001\end{array}$ \\
\hline
\end{tabular}

Source: Project Impact 


\section{APPENDIX F}

Summary of Results

Gender/Function

\begin{tabular}{|c|c|}
\hline retu & \\
\hline $\begin{array}{c}\text { Males } \\
\text { Technical }\end{array}$ & $\begin{array}{l}\text { Most notable trait is that Technical Males freely mix the concepts of improve, new and } \\
\text { change. This is true when comparing Gen Y and Gen X. Generation Y certainly highlights the } \\
\text { human contribution while Generations X has a more traditional view. Explained Variation, } \\
\text { Bartlett's test statistics are acceptable. The Kaiser-Meyer-Olin statistic is marginal. Numbers } \\
\text { of "Baby Boom" generation respondents were insufficient for factor analysis. }\end{array}$ \\
\hline $\begin{array}{l}\text { Females } \\
\text { Technical }\end{array}$ & $\begin{array}{l}\text { Again, a pattern of non-conformity for Generation Y appears. Technical Individuals perceive } \\
\text { innovation as more a conglomerate approach, rather than the three proposed categories. } \\
\text { Generation X, has a more tradition approach (aligns with the three proposed dimensions). } \\
\text { Explained Variation, Bartlett's test and Kaiser-Meyer-Olin statistics are acceptable. Numbers } \\
\text { of "Baby Boom" generation respondents were insufficient for factor analysis. }\end{array}$ \\
\hline $\begin{array}{c}\text { Females } \\
\text { Non-Technical }\end{array}$ & $\begin{array}{l}\text { The "Baby Boom" generation identified } 4 \text { unique factors. Both Gen X and Gen Y are similar } \\
\text { in terms of understanding innovation as "something new" or an improvement or change made. } \\
\text { The "Baby Boomers" also include adopting best practices and fining the best people. } \\
\text { Explained variation is marginal but the sampling adequacy and Bartlett's test meet } \\
\text { requirements. }\end{array}$ \\
\hline $\begin{array}{c}\text { Males } \\
\text { Non-Technical }\end{array}$ & $\begin{array}{l}\text { For this group, there is a definite understanding that innovation is about things that are new } \\
\text { and improved. The concept of change (or diffusion, Zhuang, 1995) is a bit more muted with } \\
\text { an emphasis on the need for finding and adopting best practices and best persons. }\end{array}$ \\
\hline
\end{tabular}

